\title{
CORPORATE SOCIAL RESPONSIBILITY ENGAGEMENT, ECONOMIC POLICY UNCERTAINTY, AND FIRM FINANCIAL PERFORMANCE
}

\author{
Sammy G. Muriithi \\ University of Central Oklahoma • Edmond, OK \\ Bruce A. Walters \\ Louisiana Tech University $\bullet$ Ruston, LA \\ Otis W. Gilley \\ Louisiana Tech University • Ruston, LA
}

\section{ABSTRACT}

The link between corporate social responsibility (CSR) engagement and firm financial performance has been examined in a variety of contexts. We extend this link to an understudied but important context for strategic decisions: environmental uncertainty. We draw on stakeholder theory to investigate the potential moderating influence of an increasingly important measure of environmental uncertainty economic policy uncertainty (EPU), on the CSR-performance relationship. Panel data analysis of 484 firms using KLD data and the Compustat/Capital IQ database reveal that EPU appears to moderate the relationship between CSR and financial performance. Moreover, supplemental analysis reveals that this moderated relationship varies when considering individual components of CSR. Implications for both research and practice are suggested regarding managers' emphases among various CSR initiatives in times of high policy uncertainty.

KeyWords: Corporate social responsibility; uncertainty; policy uncertainty; firm performance; stakeholder theory.

\section{INTRODUCTION}

Corporate social responsibility (CSR) has been defined as "actions that appear to further some social good, beyond the interest of the firm and that which is required by law" (McWilliams \& Siegel 2001: 117). The benefits firms derive from engagement in CSR initiatives have been debated. Some question whether such actions are an overinvestment of investors' contributions (Barnea \& Rubin, 2010), or perhaps the result of entrenched managers' empire-building efforts (e.g., Gul, Krishnamurti, Shams, \& Chowdhury, 2020). An opposing view is that CSR engagement is required by managers on a variety of fronts, implying that the interests of multiple stakeholders, including shareholders, are somehow balanced 
(e.g., Freeman, 1984; Wood, 1991). In their investigation of corporate governance structures' impact on CSR and financial performance, Harjoto and Jo (2011) pitted agency theory's overinvestment hypothesis against stakeholder theory's conflict resolution hypothesis, concluding that the conflict resolution hypothesis was supported whereas the overinvestment argument was not. They argued that not only is CSR engagement influenced by firm governance, but after taking into account various endogeneity issues, CSR also enhances firm financial performance. Evidence continues to accumulate pointing to reputational benefits accruing to CSR firms and the impact of CSR on financial performance (e.g., Cespa \& Cestone, 2007; George, Dahlander, Graffin, \& Sim, 2016; Wang, Dou, \& Jia, 2016).

We aim to advance our understanding of the CSR-firm performance link in a context that is critically germane to strategic decision-making, and yet has received surprisingly little research attention - the context of environmental uncertainty. A substantial body of research supports the moderating effect of uncertainty on the performance impact of strategy (Song, Augustine, \& Yang, 2016; Srećković, 2018), structure (Leifer \& Huber, 1977; Sine, Mitsuhashi \& Kirsch, 2006), and strategic decision processes (Brouthers, Brouthers, \& Werner, 2000), to name just a few examples. Yet the only widely-known study to our knowledge that investigates environment's effect on the CSR-firm performance relationship is that of Goll and Rasheed (2004). These authors investigated the moderating influence of environment on the impact of discretionary social responsibility on financial performance. They reported that environmental dynamism and munificence exert a moderating influence on the link between discretionary social responsibility and financial performance. In that study, environmental dynamism and munificence were measured as variability and growth rate in the value of shipments. Their proxy for executives' perceptions of their firms' discretionary CSR was a three-item survey measure adapted from Aupperle (1984). The authors concluded that discretionary social responsibility contributed more strongly to performance when environmental munificence and dynamism were higher.

Our study extends and builds upon the work of these authors both theoretically and methodologically. Our assessment of firms' CSR engagement is obtained from the Kinder, Lydenberg, and Domini (KLD) database because of its comprehensive assessment of a range of CSR initiatives, its broad support in CSR studies, and its construct validity (Hillman \& Keim, 2001; Mattingly \& Berman, 2006; Sharfman, 1996). The range of issues examined allows us initially to assess CSR as a global construct, and subsequently disaggregate CSR into individual components to explore differences among their effects. Our measure of uncertainty-economic 
policy uncertainty (EPU) (Baker, Bloom, \& Davis, 2016) - is a pervasive objective measure that has been widely used in recent studies and is shown to affect investment decisions (Gulen \& Ion, 2015). In contrast to environmental uncertainty concerning the variability in growth rate and the value of shipments (measures of environmental dynamism and munificence), the present focus is more specifically uncertainty about economic policy; government regulations; future federal tax code changes; and economic forecasts of government spending and the consumer price index, which represent fiscal and monetary policy uncertainty.

We find that CSR is positively associated with firm financial performance. Additionally, EPU is negatively related both to CSR and firm financial performance. As EPU increases, the positive association of CSR on financial performance appears to diminish. In subsequent analysis, interesting differences emerge regarding the relationship between individual CSR components and financial performance in the face of high policy uncertainty. The following sections present theoretical arguments and hypotheses concerning CSR and financial performance, as well as the potential moderating influence of EPU on performance. Then we present our sample and methodology, along with results using CSR in the aggregate. Subsequent analysis demonstrates that some individual CSR initiatives appear to be associated with higher performance under conditions of high EPU whereas others do not. We conclude with discussion and implications for research and practice.

\section{THEORY AND HYPOTHESES}

Firm reputation and stakeholder welfare derived from CSR engagement are important components of long-term stockholder wealth maximization and survival (Becchetti, Ciciretti, Hasan, \& Kobeissi, 2012). Investments in CSR are different from other forms of expenditures in tangible or intangible assets because the benefits are indirect, stemming from the reputational capital the firm garners from the visibility of its socially responsible endeavors (Udayasankar, 2008). In addition, these investments are largely at the discretion of the top managers and will depend on, for example, the managers' values and power in the organization (Le et al., 2015) as well as the economic environment, competition, and the legal environment (Campbell, 2007).

The conflict resolution hypothesis (Harjoto \& Jo, 2011) appears to have gained substantial credence. Firms renowned for their CSR initiatives often enjoy higher financial performance (Barnett \& Salomon, 2012), in part because of positive evaluations on the part of numerous stakeholders (George et al., 2016). A CSR 
reputation may lower the cost of capital (Sharfman \& Fernando, 2008) as well as capital constraints (Cheng et al., 2014). The investment community has been shown to react favorably to CSR initiatives (Coffey \& Fryxell, 1991; Flammer, 2013), frequently resulting in lower market risk (Bansal \& Clelland, 2004). Security analysts often follow such firms with interest, and their assessments tend to be positive (Ioannou \& Serafeim, 2015; Luo, Wang, Raithel, \& Zheng, 2015). CSR has been touted as providing "insurance-like" benefits against negative environmental events that threaten firm value (Godfrey, Merrill, \& Hansen, 2009; McGuire, Sundgren, \& Schneeweis, 1988) as well as litigation risk (Koh, Qian, \& Wang, 2014).

Firms in which management genuinely commits to CSR engagement have also been shown to benefit from a culture in which employees exhibit great efforts for the good of the firm. Such firms tend to have increased employee creativity, innovation, and engagement (Caligiuri et al., 2013; Glavas \& Piderit, 2009), as well as higher employee retention (Jones, 2010) and commitment (Maignan et al., 1999). They often are at an advantage in attracting job applicants (Lin et al., 2010). Their enhanced image and reputation broadens their choice set among a greater number of highly qualified potential employees as compared to low-CSR firms (Fombrun \& Shanley, 1990). Turnover is reduced as committed employees experience intrinsic job satisfaction and identification with the organization and its goals (Brammer et al., 2007; Peterson, 2004). Corporate leaders with a stakeholder orientation have been shown to be perceived as visionary leaders that spur employees to make personal sacrifices for the firm (Sully de Luque et al., 2008). The accompanying organizational citizenship behaviors stimulate working relationships and enhance job performance (Kim et al., 2010; Lin et al., 2010).

The foregoing characteristics attributed to CSR firms set the stage for increased financial performance. Such firms are endowed with a degree of moral capital that engages various stakeholders in a positive way (Godfrey, 2005), and constituents respond in part because of signals CSR evokes, such as customers' evaluations (Arora \& Henderson, 2007; Maignan et al., 1999). Employee commitment, engagement, creativity, and innovation are likely to enhance financial performance from within, while key external stakeholders can be expected to provide needed resources. These arguments lead to the following hypothesis: 
Hypothesis 1: CSR is positively related to firm financial performance.

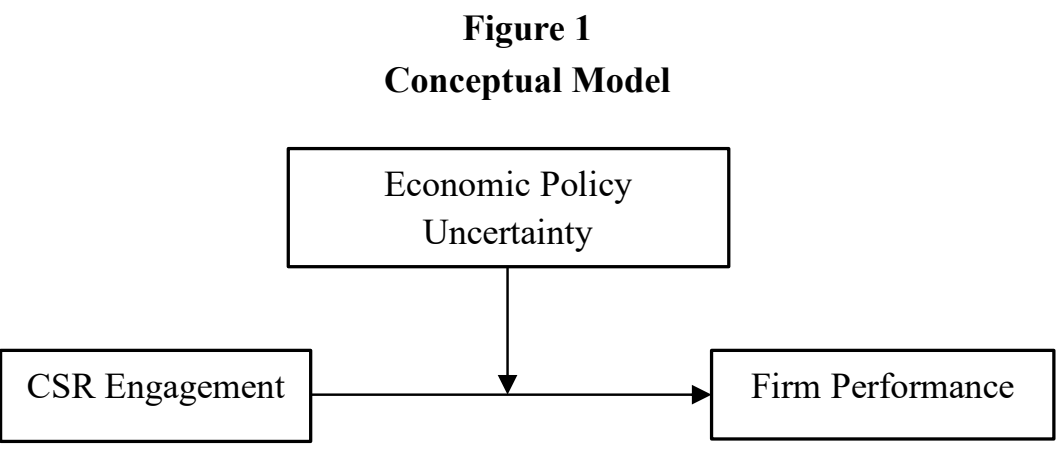

\section{Policy Uncertainty Effects}

Recent studies have begun to investigate the effect of contextual factors on firms' investment in CSR. For example, Wang et al. (2016) and Julian and Ofori-Dankwa (2013) conclude that institutional differences between advanced economies and developing economies are likely to result in different CSR implications. Goll \& Rasheed (2004) investigated the moderating influence of environmental dynamism and munificence on the relationship between discretionary social responsibility and firm financial performance. These studies reinforce the importance of environmental characteristics as a key driver of CSR, hence the need for further inquiry into their influence.

National domains harbor different contextual factors such as the political, social, and economic institutions that ultimately affect firms' growth and profitability (Khanna \& Rivkin, 2001; North, 1990). The government plays an important role in influencing the performance of firms (Porter, 1990) within these domains given its impact on the policy environment. Policy uncertainty becomes especially important due to its profound power over the performance of the economy, the markets, the industry, and ultimately the firm. The policy environment has been defined as the set of laws, regulations, and administrative procedures formally sanctioned by the government that impact a firm's profitability by altering its costs or revenues (Delios $\&$ Henisz, 2003). Policy uncertainty may increase as the number of veto players within their political institutions declines or as they become more homogeneous (Henisz \& Delios, 2004). Therefore, where sufficient checks and balances exist, for example, within the executive, legislative, and judicial branches, the political elite are limited in the breadth of action they can take by other political actors who must approve any proposed changes in policy (Henisz, 2000; North, 1990). 
The policy environment may be characterized by varying levels of uncertainty. Policy uncertainty is unlike other types of risk (e.g., contracting or input-price uncertainty) because it is beyond the firm's control and cannot be hedged (Bonaime et al., 2018). While firms within a given national institutional context rationally pursue their interests and make strategic choices (Lee, Peng, \& Barney, 2007), policy uncertainty serves to cloud management's judgment of various strategic options at their disposal. Policy uncertainty has been found to adversely affect asset returns, firm-level investment, firm acquisitiveness, and innovation activity (Bhattacharya et al., 2017; Brogaard \& Detzel, 2015; Chen et al., 2019; Gulen \& Ion, 2015; Kang et al., 2014; Nguyen \& Phan, 2017). Adverse effects associated with high EPU include increases in the cost of external financing (Gilchrist et al., 2014) and firm cash holdings (Phan et al., 2019).

As EPU cannot be hedged through firm actions (Bonaime et al., 2018), organizational researchers have traditionally viewed uncertainty as a threat to the organization (Kogut \& Kulatilaka, 2001). Indeed, studies have found that policy uncertainty not only raises the costs of new equity and debt (Gungoraydinoglu, Çolak, \& Öztekin, 2017), but also negatively affects investments in tangible assets (Alesina \& Perotti, 1996; Bloom, Bond, and Van Reenen, 2007; Gulen \& Ion, 2015; Julio \& Yook, 2012), lowers firm engagement in mergers and acquisitions (Nguyen $\&$ Phan, 2017), and negatively impacts innovation (Bhattacharya et al., 2017). Given these outcomes, the real options perspective would suggest that during times of high policy uncertainty the option to postpone current investment would have a higher value for the firm. Managers would likely adopt a more cautious approach to investment, putting off investments to a future they anticipate will be more stable and predictable, potentially leading to a decrease in the level of organizational performance. Conversely, during times of low uncertainty, the external environment would be more predictable and the future outcomes of current investments would be more feasible to forecast. Managers would be more likely to increase investments due to their confidence in making them. Given their discretionary nature, CSR investments might be among those to be eliminated or postponed during times of high policy uncertainty. It follows that, with lower CSR engagement, the potential positive outcomes from these CSR investments will be diminished, leading to lower overall financial performance. However, during times of low policy uncertainty, managers would be more confident making investments in CSR, implying that the organization would reap greater benefits from engaging in CSR. We therefore propose that policy uncertainty will negatively moderate the relationship between CSR and CFP. 
Hypothesis 2: Policy uncertainty negatively moderates the relationship between CSR and firm financial performance.

\section{METHODOLOGY}

Our data were obtained from the MSCI KLD database (henceforth KLD), the Baker et al. (2016) policy uncertainty index (hereafter, BBDI), and Compustat/ Capital IQ. Sample collection began with all US firms that consistently appear in the KLD database from 2001-2010. For these firms, financial measures were obtained from the Compustat/Capital IQ database, while the annual policy uncertainty measure was obtained from BBDI. After excluding firms with missing data, our final dataset consisted of 484 firms.

\section{Variables}

Our measure for CSR, our independent variable, is derived for the years 20012010 from the KLD database. The database objectively analyzes firm CSR along 13 dimensions and assigns scores ranging from +1 (strength) to -1 (weakness), with 0 being a neutral score. Five of these dimensions are directly attributable to stakeholders and are frequently used in research (community, diversity, employee relations, environment, and product). Following convention, we obtained each firm's overall CSR score by summing its strengths and weaknesses along the five dimensions (e.g., Johnson \& Greening, 1999).

This study assesses the relationship between CSR and firm financial performance as well as the potential moderating influence of policy uncertainty on the CSR-performance relationship. Financial performance was obtained as the ROA (Net income/Total assets) for the focal year. For our moderating variable, economic policy uncertainty (EPU), we utilized the Baker et al. (2016) policy uncertainty index (BBDI). This index has been widely used in recent literature as a credible measure of policy uncertainty (e.g., Gulen \& Ion, 2015; Hadani et al., 2016). EPU is constructed as a weighted average measure of (i) the frequency of newspaper articles related to policy uncertainty; (ii) uncertainty about future federal tax code changes; and (iii) dispersion in economic forecasts of government spending and the consumer price index, which represent fiscal and monetary policy uncertainty. For purposes of this study, the BBDI is advantageous in that it objectively quantifies environmental uncertainty dimensions, decreasing concerns of bias and validity inherent in perceptual measures of uncertainty (Buchko, 1994). 


\section{Control Variables}

Firm Size: Larger firms are likely better endowed with resources, which may raise the availability of resources to spend on CSR initiatives. In addition, they are likely to invest more in CSR initiatives because of the greater public scrutiny over their behavior (Christmann \& Taylor, 2001).

Debt Ratio: Extant research indicates that debt encourages restraint on managers, thereby limiting the exploration of new business and lowering profit potential, and motivates managers to make decisions that are in line with the interests of the firm (Barnett \& Salomon, 2012). Debt ratio is obtained by dividing the firm's long-term debt by total assets.

Year Effects: Specific trends occurring in some years may affect firm financial performance (Banalieva \& Santoro, 2009). To control for this possibility, dummy variables were created for each of our sampling years.

Advertising Intensity: Marketing efforts can be used to enhance competitive positioning and profitability (McWilliams \& Siegel, 2000). Advertising intensity is measured as the ratio of advertising expenditures to sales (Barnett \& Salomon, 2012).

Industry Effects: Extant research suggests that industry characteristics can affect changes in customer tastes, competitor behavior, technology, and sources of supply (Lawrence \& Lorsch, 1967), which may ultimately affect profitability of firms within them. Dummy variables were created using the first two digits of the SIC of each focal firm.

Prior Performance: Prior performance affects subsequent performance through its influence on managerial strategic decision-making processes (Hambrick \& Schecter, 1983; Tushman \& Romanelli, 1985; Wiersema \& Bantel, 1992). This was operationalized as the average ROA for the three years prior to the focal year.

Organizational Slack: Slack represents "a cushion of actual or potential resources which allow an organization to adapt successfully to internal pressures for adjustment or to external pressures for change in policy, as well as to initiate changes in strategy with respect to the external environment" (Bourgeois, 1981: 30). Slack resources can be used as a safeguard against the negative effects of uncertainty (Reuer \& Leiblein, 2000) and can therefore have a substantial impact on firm performance (Iyer \& Miller, 2008). Slack also makes the firm less resistant to 
stakeholder demands (Tang \& Tang, 2012), potentially affecting firm investments in CSR. Slack was operationalized as the average cash and cash equivalents over the three year period prior to the focal year (Le, Park \& Kroll, 2014)

\section{EMPIRICAL RESULTS}

A majority of studies of the effects of corporate social responsibility on firm performance have relied on cross-sectional datasets in investigating this relationship. A key distinction in the present study is that we make use of a panel dataset. This offers several important advantages over previous investigations. First, our panel of data consists of observations on 484 firms over a span of 10 years. Second, since firms and their shareholders are by nature idiosyncratic, panel analysis allows us to overcome coefficient bias resulting from unobserved heterogeneity and omitted variables. Third, panel data are better suited than cross-sectional data for studying the dynamics of change. Fourth, panel data can minimize the effects of aggregation bias that might arise from aggregating firms into broad groups such as by industry.

Descriptive statistics and correlations are presented in Table 1. We estimated a standard fixed effects panel model that regresses changes in the dependent variable against changes in the explanatory variables, thereby differencing out any unobserved heterogeneity. Results of the firm fixed effects model utilizing robust clustered standard errors appears in Table 2.

\section{Table1}

\section{Descriptive Statistics and Correlation}

\begin{tabular}{|c|c|c|c|c|c|c|c|c|c|c|c|c|c|c|}
\hline Variables & Mean & SD & 1 & 2 & 3 & 4 & 5 & 6 & 7 & 8 & 9 & 10 & 11 & 12 \\
\hline 1. Overall CSR & 0.58 & 2.92 & 1.00 & & & & & & & & & & & \\
\hline 2. Product CSR & -0.39 & 0.86 & 0.25 & 1.00 & & & & & & & & & & \\
\hline 3. Environment CSR & -0.04 & 1.13 & 0.59 & 0.14 & 1.00 & & & & & & & & & \\
\hline 4. Employee CSR & -0.08 & 1.10 & 0.52 & 0.12 & 0.06 & 1.00 & & & & & & & & \\
\hline 5. Community CSR & 0.18 & 0.76 & 0.55 & -0.12 & 0.26 & 0.08 & 1.00 & & & & & & & \\
\hline 6. Diversity CSR & 0.91 & 1.56 & 0.67 & -0.21 & 0.14 & 0.12 & 0.37 & 1.00 & & & & & & \\
\hline 7. Policy Uncertainty & 105.07 & 35.55 & 0.07 & 0.01 & 0.17 & 0.03 & 0.04 & -0.03 & 1.00 & & & & & \\
\hline 8. Organizational Slack & 2.64 & 0.81 & 0.22 & -0.36 & 0.01 & 0.11 & 0.27 & 0.40 & 0.02 & 1.00 & & & & \\
\hline 9. Prior Performance & 0.05 & 0.07 & 0.13 & 0.06 & 0.05 & 0.11 & 0.04 & 0.08 & -0.01 & -0.05 & 1.00 & & & \\
\hline 10. Advertising Intensity & 1.03 & 10.29 & 0.01 & 0.02 & 0.01 & 0.07 & -0.03 & -0.02 & 0.00 & -0.02 & 0.04 & 1.00 & & \\
\hline 11. Debt Ratio & 0.20 & 0.16 & -0.15 & -0.05 & -0.07 & -0.15 & -0.09 & -0.05 & 0.07 & -0.22 & -0.21 & -0.07 & 1.00 & \\
\hline 12. Firm Size & 3.85 & 0.66 & 0.10 & -0.45 & -0.13 & 0.02 & 0.21 & 0.42 & 0.01 & 0.71 & -0.11 & -0.06 & 0.02 & 1.00 \\
\hline
\end{tabular}


Table2

Results of Panel Fixed-effects Model DV: Financial Performance

\begin{tabular}{|c|c|c|c|c|c|c|}
\hline & \multicolumn{2}{|c|}{ Model 1} & \multicolumn{2}{|c|}{ Model 2} & \multicolumn{2}{|c|}{ Model 3} \\
\hline & $\mathrm{a}$ & $b$ & $\mathrm{a}$ & $b$ & $\mathrm{a}$ & $\mathrm{b}$ \\
\hline Firm Size & & $\begin{array}{c}0.00097 \\
(0.07)\end{array}$ & & $\begin{array}{c}0.00316 \\
(0.22)\end{array}$ & & $\begin{array}{c}0.00202 \\
(0.14)\end{array}$ \\
\hline Debt Ratio & & $\begin{array}{c}-0.14779 * * * \\
(-3.99)\end{array}$ & & $\begin{array}{c}-0.14877 * * * \\
(-3.96)\end{array}$ & & $\begin{array}{c}-0.14868 * * * \\
(-3.96)\end{array}$ \\
\hline Advertising Intensity & & $\begin{array}{c}-0.00036^{* * *} \\
(-3.83)\end{array}$ & & $\begin{array}{c}-0.00038^{* * * *} \\
(-4.43)\end{array}$ & & $\begin{array}{c}-0.00038^{* * *} \\
(-4.28)\end{array}$ \\
\hline Prior Performance & & $\begin{array}{c}-0.02074 \\
(-0.37)\end{array}$ & & $\begin{array}{c}-0.01242 \\
(-0.22)\end{array}$ & & $\begin{array}{c}-0.01113 \\
(-0.20)\end{array}$ \\
\hline Organizational slack & & $\begin{array}{c}0.00722 \\
(1.65)\end{array}$ & & $\begin{array}{c}0.00727 \\
(1.65)\end{array}$ & & $\begin{array}{c}0.0072 \\
(1.64)\end{array}$ \\
\hline EPU & $\begin{array}{c}-0.00029 * * * \\
(-8.18)\end{array}$ & $\begin{array}{c}-0.00029 * * * \\
(-8.42)\end{array}$ & $\begin{array}{c}-0.00027^{* * * *} \\
\quad(-8.03)\end{array}$ & $\begin{array}{c}-0.00030 * * * \\
(-8.23)\end{array}$ & $\begin{array}{c}-0.00027^{* * *} \\
\quad(-8.03)\end{array}$ & $\begin{array}{c}-0.00028^{* * * *} \\
\quad(-8.15)\end{array}$ \\
\hline Overall CSR & $\begin{array}{c}0.00352 * * * \\
\quad(4.03)\end{array}$ & $\begin{array}{c}0.00261 \\
(1.77)\end{array}$ & & & & \\
\hline Overall CSR x EPU & & $\begin{array}{c}0.00001 \\
(0.96)\end{array}$ & & & & \\
\hline Diversity CSR & & & $\begin{array}{c}-0.00082 \\
(-0.53)\end{array}$ & $\begin{array}{c}-0.00449 * \\
(-2.06)\end{array}$ & & \\
\hline Diversity CSR x EPL & & & & $\begin{array}{c}0.00003^{*} \\
(2.31)\end{array}$ & & \\
\hline Community CSR & & & & & $\begin{array}{c}0.00254 \\
(1.30)\end{array}$ & $\begin{array}{c}-0.00554 \\
(-1.30)\end{array}$ \\
\hline Community CSR x E & PU & & & & & $\begin{array}{c}0.00008^{*} \\
(2.12)\end{array}$ \\
\hline Constant & & $\begin{array}{c}0.08541 \\
(1.78) \\
\end{array}$ & & $\begin{array}{c}0.08039 \\
(1.65) \\
\end{array}$ & & $\begin{array}{c}0.08169 \\
(1.68) \\
\end{array}$ \\
\hline $\begin{array}{l}\text { F } \\
{ }^{a} \text { Marginal Effects }(d) \\
\text { t statistics in parenthe } \\
* p<0.05 \\
* * p<0.01 \\
* * * p<0.001\end{array}$ & $\begin{array}{l}\text { y/dx); }{ }^{b} \text { Mode } \\
\text { eses }\end{array}$ & $\begin{array}{c}20.32642 \\
\text { el Coefficients }\end{array}$ & & 20.49354 & & 20.07202 \\
\hline
\end{tabular}


Table 2 Continued

Results of Panel Fixed-effects Model DV: Financial Performance

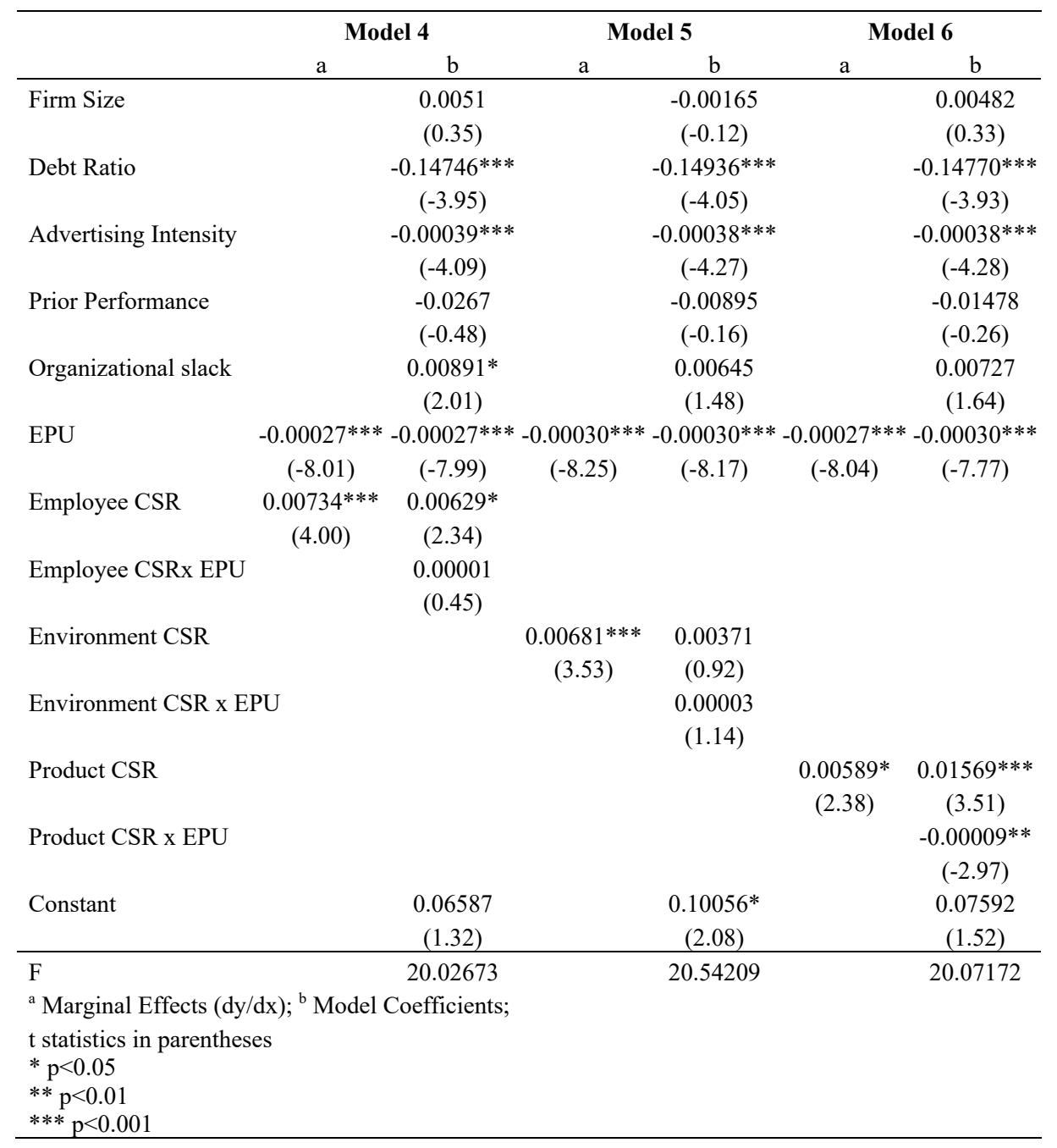


The dependent variable is the change in return on assets and the model includes an interaction between policy uncertainty and corporate social responsibility to capture the possible mitigating effects. The main question of importance is if and how corporate social responsibility might mitigate the potential negative effects of policy uncertainty if such effects exist. To answer this question, we report the average marginal effects from the fixed effects model (Model 1a). These marginal effects isolate the effect of a change in each variable holding all else constant and account for the potential interaction of the variables. From these results we see that policy uncertainty, in line with our expectations, is negatively and significantly related to the change in return on assets $(-0.00029, p<0.001)$. We also see that the marginal effect of corporate social responsibility is positive and significant $(0.00352$, $\mathrm{p}<0.001$ ), which is in line with prior research supporting the beneficial outcomes of CSR engagement for firms, providing support for Hypothesis H1.

These results suggest that CSR may have the potential to offset the negative effects of policy uncertainty. To test this proposition, we include policy uncertainty as a moderator in the CSR-performance relationship in Model 1b. The coefficient of the interaction is found to be insignificant (0.00001), suggesting no moderation when considering overall CSR as an aggregate measure. The possibility that effects of individual components were masked by such aggregation is quite conceivable, motivating us to de-compartmentalize CSR in subsequent analysis.

Thus far, our analysis has relied on the aggregate CSR measure composed of community, diversity, employee relations, environment, and product dimensions as reflected in the KLD scores. Prior research suggests that various CSR dimensions may affect profitability in unique ways. To increase understanding of the relationship between EPU and the CSR-profitability link, supplemental analyses were performed (Model 2 through Model 6). Model 2 tests the effect of the diversity dimension on performance. Model 2a reports the marginal effects of the diversity dimension on performance, which are found to be insignificant $(-0.00082)$. However, the interaction depicted in Model $2 \mathrm{~b}$ is positive and significant $(0.00003, \mathrm{p}<0.05)$, suggesting that, when policy uncertainty is high, engagement in diversity-related CSR may be beneficial to the bottom line for firms.

Model 3 tests the effect of community CSR on performance. Similar to the diversity dimension, the marginal effect is insignificant. However, the interaction term is significant $(0.00008, \mathrm{p}<0.05)$, implying that engagement in communityrelated CSR may mitigate the negative effects of high policy uncertainty.

Model 4 tests the effect of employee CSR on performance. The marginal effect (Model $4 \mathrm{a})$ is highly significant $(0.00734, \mathrm{p}<0.001)$, meaning that employee CSR is highly 
related to organizational performance. However, the employee CSR-policy uncertainty interaction term (Model $4 \mathrm{~b}$ ) is insignificant (0.00001), so regardless of the uncertainty level, performance is not significantly affected by the level of policy uncertainty.

Model 5 tests the effect of environment CSR on performance, and the moderating effect of policy uncertainty on that relationship. The marginal effect in Model $5 \mathrm{a}$ is positive and significant $(0.00681, \mathrm{p}<0.001)$, suggesting that engagement in environment CSR is beneficial for financial performance. However, the interaction effect of EPU on the CSR-FP relationship in Model 5b is not supported.

Model 6 tests the effect of product CSR on the CSR-FP relationship. Results of the marginal analysis in Model $6 \mathrm{a}$ are positive and significant $(0.00589, \mathrm{p}<0.05)$, suggesting that engagement in product-related CSR is beneficial for financial performance. However, the interaction effect in Model $6 \mathrm{~b}$ is negative and significant $(-0.00009, p<0.01)$, suggesting that policy uncertainty reverses the positive outcomes of engagement in product-related CSR activities.

These results suggest that economic policy uncertainty has a negative and significant effect on the change in return on assets. Additionally, the marginal effect of corporate social responsibility is positive and significant, potentially offsetting the effects of policy uncertainty. Contrary to our expectations, economic policy uncertainty does not appear to moderate the relationship between CSR and performance when considering CSR as an aggregate measure. Importantly, individual components of CSR demonstrate unique effects regarding the observed relationships. Thus, disaggregating the CSR construct can bring to light potential relationships among CSR, performance, and context that may otherwise be masked.

\section{DISCUSSION}

This study explores the relationship between socially responsible activities and firm financial performance and the potential moderation effects of an increasingly important and pervasive type of environmental uncertainty-economic policy uncertainty. A substantial body of research has been conducted on the effect of CSR on financial performance, and we had the opportunity to confirm this relationship in another setting as well as extend the pioneering work of Goll and Rasheed (2004), both theoretically and methodologically. These authors found environmental characteristics to moderate the CSR-performance relationship. Our extensions include the use of KLD data to assess the relationship overall as well as separate CSR dimensions, and inclusion of an important dimension of environmental uncertainty-economic policy uncertainty. Methodologically, we assessed these 
relationships using marginal analysis of panel data, along with objective measures of CSR and EPU.

Results indicate that the relationship between CSR and financial performance is generally positive and significant in our sample, lending further credence to the positive outcomes that accompany CSR engagement. CSR engagement continues to gain prominence among stakeholders as a salient performance dimension. Contemporaneously, environmental uncertainty is on the rise globally. These conditions set the stage for research that illuminates how specific aspects of uncertainty may affect the CSR-financial performance relationship. After investigating this relationship initially in terms of overall CSR using aggregated KLD data, we then disaggregate CSR into five unique dimensions in subsequent analysis. The results help to uncover differences in the apparent salience of each dimension, both in terms of main effects and as moderated by economic policy uncertainty.

Our supplemental analysis indicates that individual categories of CSR engagement may demonstrate unique effects at given levels of policy uncertainty even as, in some cases, the main effects may not be apparent. For instance, although the diversity dimension of CSR is not demonstrated to be related to performance, when EPU is high, engagement in diversity-related CSR may boost the bottom line. Community-related CSR similarly seems to mitigate the negative link between high policy uncertainty and performance. On the other hand, environment- and employeerelated CSR appear important for financial performance whether policy uncertainty is high or low. And while product-related CSR benefits financial performance, the negative interaction suggests high EPU reverses such positive benefits. In other words, product CSR appears to pay off more when EPU is low. In addition, these have varying effect sizes, implying that payoffs from different dimensions of CSR may differ depending on the level of economic policy uncertainty facing the firm.

Obviously these findings should be taken with caution. But they do imply that researchers may extend our knowledge by considering specific categories of CSR engagement in different environmental contexts. For example, investigation of whether some types of CSR are more beneficial in particular institutional settings, in line with Wang and colleagues (2016) and Julian and Ofori-Dankwa (2013), would be warranted. Various stakeholder groups stand to benefit from CSR engagement. This study indeed finds that, while this is true, the benefits accruing to the firm may vary with the level of environmental uncertainty. We thus contribute to the literature exploring the degree to which serving stakeholders might enhance firm performance, and also to CSR literature by exploring the influence of CSR dimensions as disaggregated from an overall construct. 
This study is not without limitations. First, the reliance on KLD data, an objective measure of CSR, may not adequately capture actual stakeholder sentiment of a firm's social engagement. In a similar fashion, although Baker and colleagues' (2016) economic policy uncertainty index is arguably a prominent objective measure of EPU and has been used in numerous studies, it may not always accurately capture executives' perceptions of the current level of uncertainty in the environment. Future empirical studies may add value by employing survey methods in assessing stakeholders' perceptions of firms' CSR initiatives as well as executives' perceptions of economic policy uncertainty and its ramifications for success.

\section{REFERENCES}

Alesina, A., \& Perotti, R. (1996). Income distribution, political instability, and investment. European Economic Review, 406, 1203-1228.

Arora, N., \& Henderson, T. (2007). Embedded premium promotion: Why it works and how to make it more effective. Marketing Science, 26, 514-531.

Aupperle, K. E. (1984). An empirical measure of corporate social orientation. In L. E. Preston (ed.), Research in corporate social performance and policy, 6, 27-54. Greenwich, CT: JAI Press.

Baker, S. R., Bloom, N., \& Davis, S. J. (2016). Measuring economic policy uncertainty. The Quarterly Journal of Economics, 131, 1593-1636.

Banalieva, E. R., \& Santoro, M. D. (2009). Local, regional, or global? Geographic orientation and relative financial performance of emerging market multinational enterprises. European Management Journal, 27, 344-355.

Bansal, P., \& Clelland, I. (2004). Talking trash: Legitimacy, impression management, and unsystematic risk in the context of the natural environment. Academy of Management Journal, 47, 93-103.

Barnea, A., \& Rubin, A. (2010). Corporate social responsibility as a conflict between shareholders. Journal of Business Ethics, 97, 71-86.

Barnett, M. L., \& Salomon, R. M. (2012). Does it pay to be really good? Addressing the shape of the relationship between social and financial performance. Strategic Management Journal, 33, 1304-1320.

Becchetti, L.,Ciciretti, R., Hasan, I., \& Kobeissi, N. (2012). Corporate social responsibility and shareholder's value. Journal of Business Research, 65, 1628-1635.

Bhattacharya, U., Hsu, P., Tian, X., \& Xu, Y. (2017). What affects innovation more: policy or policy uncertainty? Journal of Financial and Quantitative Analysis, 52, 1869-1901. 
Bloom, N., Bond, S., \& Van Reenen, J. (2007). Uncertainty and investment dynamics. The Review of Economic Studies, 74, 391-415.

Bonaime, A., Gulen, H., \& Ion, M. (2018). Does policy uncertainty affect mergers and acquisitions? Journal of Financial Economics, 129, 531-558.

Bourgeois III, L. J. (1981). On the measurement of organizational slack. Academy of Management Review, 6, 29-39.

Brammer, S., Millington, A., \& Rayton, B. (2007). The contribution of corporate social responsibility to organizational commitment. International Journal of Human Resource Management, 18, 1701-1719.

Brogaard, J., \& Detzel, A. (2015). The asset-pricing implications of government economic policy uncertainty. Management Science, 61, 3-18.

Brouthers, K. D., Brouthers, L. E., \& Werner, S. (2000). Influences on strategic decision-making in the Dutch financial services industry. Journal of Management, 26, 863-883.

Buchko, A. A. (1994). Conceptualization and Measurement of environmental uncertainty: an assessment of the miles and snow perceived environmental uncertainty scale. Academy of Management Journal, 37, 410-425.

Caligiuri, P., Mencin, A., \& Jiang, K. (2013). Win-win-win: The influence of company-sponsored volunteerism programs on employees, NGOs, and business units. Personnel Psychology, 66, 825-860.

Campbell, J. L. (2007). Why would corporations behave in socially responsible ways? An institutional theory of corporate social responsibility. Academy of management Review, 32, 946-967.

Cespa, G., \& Cestone, G. (2007). Corporate social responsibility and managerial entrenchment. Journal of Economics \& Management Strategy, 16, 741-771.

Chen, P. F., Lee, C. C., \& Zeng. J. H. (2019). Economic policy uncertainty and firm investment: evidence from the US market. Applied Economics, 51, 3423-3435.

Cheng, B., I. Ioannou., \& Serafeim, G. (2014). Corporate social responsibility and access to finance. Strategic Management Journal, 35, 1-23.

Christmann, P., \& Taylor, G. (2001). Globalization and the environment: Determinants of firm self-regulation in China. Journal of International Business Studies, 32, 439-458.

Coffey, B. S., \& Fryxell, G. E. (1991). Institutional ownership of stock and dimensions of corporate social performance: An empirical examination. Journal of Business Ethics, 10, 437-444.

Delios, A., \& Henisz, W. J. (2003). Political hazards, experience, and sequential entry strategies: The international expansion of Japanese firms, 1980-1998. Strategic Management Journal, 24, 1153-1164. 
Flammer, C. (2013). Corporate social responsibility and shareholder reaction: The environmental awareness of investors. Academy of Management Journal, 56, 758-781.

Fombrun, C., \& Shanley, M. (1990). What's in a name? Reputation building and corporate strategy. Academy of Management Journal, 33, 233-258

Freeman R. E. (1984). Strategic management: A stakeholder approach. Pitman: Boston, MA.

Gilchrist, S., Sim, J. W., \& Zakrajšek, E. (2014). Uncertainty, Financial Frictions, and Investment Dynamics. National Bureau of Economic Research, Inc. NBER Working Papers: 20038.

Glavas A., \& Piderit, S. (2009). How does doing good matter? Effects of corporate citizenship on employees. Journal of Organizational Citizenship, 36, 51-70.

George, G., Dahlander, L., Graffin, S., \& Sim, S. (2016). Reputation and status: Expanding the role of social evaluation in management research. Academy of Management Journal, 59, 1-13.

Godfrey, P. C. (2005). The relationship between corporate philanthropy and shareholder wealth: A risk management perspective. Academy of Management Review, 30, 777-798.

Godfrey, P. C., Merrill, C. B., \& Hansen, J. M. (2009). The relationship between corporate social responsibility and shareholder value: An empirical test of the risk management hypothesis. Strategic Management Journal, 30, 425-445.

Goll, I., \& Rasheed, A. A. (2004). The moderating effect of environmental munificence and dynamism on the relationship between discretionary social responsibility and firm performance. Journal of Business Ethics, 49, 41-54.

Gul, F. A., Krishnamurti, C., Shams, S., \& Chowdhury, H. (2020). Corporate social responsibility, overconfident CEOs and empire building: Agency and stakeholder theoretic perspectives. Journal of Business Research, 111, 52-68.

Gulen, H., \& Ion, M. (2015). Policy uncertainty and corporate investment. The Review of Financial Studies, 29, 523-564.

Gungoraydinoglu, A., Çolak, G., \& Öztekin, Ö. (2017). Political environment, financial intermediation costs, and financing patterns. Journal of Corporate Finance, 44, 167-192.

Hadani, M., Bonardi, J. P., \& Dahan. N. M. (2016). Corporate political activity, public policy uncertainty, and firm outcomes: A meta-analysis. Strategic Organization, 15, 338-366.

Hambrick, D. C., \& Schecter, S. M. (1983). Turnaround strategies for mature industrialproduct business units. Academy of Management Journal, 26, 231-248. 
Harjoto, M. A., \& Jo, H. (2011). Corporate governance and CSR nexus. Journal of Business Ethics, 100, 45-67.

Henisz, W. J. (2000). The institutional environment for multinational investment. The Journal of Law, Economics, and Organization, 16, 334-364.

Henisz, W. J., \& Delios. A. (2004). Information or Influence? The benefits of experience for managing political uncertainty. Strategic Organization, 2, 389-421.

Hillman, A. J., \& Keim, G. D. (2001). Shareholder value, stakeholder management, and social issues: What's the bottom line? Strategic Management Journal, 22, 125-139.

Ioannou, I., \& Serafeim, G. (2015). The impact of corporate social responsibility on investment recommendations: Analysts' perceptions and shifting institutional logics. Strategic Management Journal, 36, 1053-1081.

Iyer, D. N., \& Miller, K. D. (2008). Performance feedback, slack, and the timing of acquisitions. Academy of Management Journal, 51, 808-822.

Johnson, R. A., \& Greening, D. W. (1999). The effects of corporate governance and institutional ownership types on corporate social performance. Academy of Management Journal, 42, 564-576.

Jones, D. A. (2010). Does serving the community also serve the company? Using organizational identification and social exchange theories to understand employee responses to a volunteerism programme. Journal of Occupational and Organizational Psychology, 83, 857-878.

Julian, S. D., \& Ofori-Dankwa, J. C. (2013). Financial resource availability and corporate social responsibility expenditures in a sub-Saharan economy: The institutional difference hypothesis. Strategic Management Journal, 34, 13141330.

Julio, B., \& Yook, Y. (2012). Political uncertainty and corporate investment cycles. The Journal of Finance, 67, 45-83.

Kang, W., Lee, K., \& Ratti, R. A. (2014). Economic policy uncertainty and firmlevel investment. Journal of Macroeconomics, 39, 42-53.

Khanna, T., \& Rivkin, J. (2001). Estimating the performance of business groups in emerging markets. Strategic Management Journal, 22, 45-74.

Kim, H. R., Lee, M., Lee, H. T., \& Kim, N. M. (2010). Corporate social responsibility and employee-company identification. Journal of Business Ethics, 95, 557-569.

Kogut, B., \& Kulatilaka, N. (2001). Capabilities as real options. Organization Science, 12, 744-758.

Koh, P. S., Qian, C., \& Wang, H. (2014). Firm litigation risk and the insurance value of corporate social performance. Strategic Management Journal, 35, 1464-1482. 
Lawrence, P. R., \& Lorsch, J. W. (1967). Organization and environment: Managing differentiation and integration. Boston, MA: Harvard Business School Press.

Le, S., Fuller, B., Muriithi, S., Walters, B., \& Kroll, M. J. (2015). The influence of top managers' values on corporate social performance: A meta-analysis. Journal of Managerial Issues, 27, 9-27.

Le, S. A., Park, J. C., \& Kroll, M. (2014). Differential effects of pre and postacquisition $\mathrm{R} \& \mathrm{D}$ expenditures on post-acquisition performance. Journal of Business Research, 67, 92-99.

Lee, S. H., Peng, M. W., \& Barney, J. B. (2007). Bankruptcy law and entrepreneurship development: A real options perspective. Academy of Management Review, 32, 257-272.

Leifer,R.,\&Huber,G.P.(1977).Relationsamong perceivedenvironmentaluncertainty, organization structure, and boundary-spanning behavior. Administrative Science Quarterly, 22, 235-247.

Lin, C. P., Lyau, N. M., Tsai, Y. H., Chen, W. Y., \& Chiu, C. K. (2010). Modeling corporate citizenship and its relationship with organizational citizenship behaviors. Journal of Business Ethics, 95, 357-372.

Luo, X., Wang, H., Raithel, S., \& Zheng, Q. (2015). Corporate social performance, analyst stock recommendations, and firm future returns. Strategic Management Journal, 36, 123-136.

Maignan, I., Ferrell, O. C., \& Hult, G. T. (1999). Corporate citizenship: Cultural antecedents and business benefits. Journal of the Academy of Marketing Science, 27, 455-469.

Mattingly, J. E., \& Berman, S. L. (2006). Measurement of corporate social action: Discovering taxonomy in the Kinder Lydenburg Domini ratings data. Business \& Society, 45, 20-46.

McGuire, J. B., Sundgren,A., \& Schneeweis, T. (1988). Corporate social responsibility and firm financial performance. Academy of Management Journal, 31, 854-872.

McWilliams, A., \& Siegel, D. (2000). Corporate social responsibility and financial performance: Correlation or misspecification? Strategic Management Journal, 21, 603-609.

McWilliams, A., \& Siegel, D. (2001). Corporate social responsibility: A theory of the firm perspective. Academy of Management Review, 26, 117-127.

Nguyen, N. H., \& Phan, H. V. (2017). Policy uncertainty and mergers and acquisitions. Journal of Financial and Quantitative Analysis, 52, 613-644.

North. (1990). Institutions, Institutional Change and Economic Performance. Cambridge, UK: Cambridge University Press. 
Peterson, D. K. (2004). The relationship between perceptions of corporate citizenship and organizational commitment. Business \& Society, 43, 296-319.

Phan, H. V., Nguyen, N. H., Nguyen, H. T., \& Hegde, S. (2019). Policy uncertainty and firm cash holdings. Journal of Business Research, 95, 71-82.

Porter, M. E. (1990). The competitive advantage of nations. Harvard Business Review, 68, 73-93.

Reuer, J. J., \& Leiblein, M. J. (2000). Downside risk implications of multinationality and international joint ventures. Academy of Management Journal, 43, 203-214.

Sharfman, M. (1996). The construct validity of the Kinder, Lydenberg \& Domini social performance ratings data. Journal of Business Ethics, 15, 287-296.

Sharfman, M. P., \& Fernando, C. S. (2008). Environmental risk management and the cost of capital. Strategic Management Journal, 29, 569-592.

Sine, W. D., Mitsuhashi, H., \& Kirsch, D. A. (2006). Revisiting burns and stalker: Formal structure and new venture performance in emerging economic sectors. Academy of Management Journal, 49, 121-132.

Song, L., Augustine, D., \& Yang, J. Y. (2016). Environmental uncertainty, prospector strategy, and new venture performance: the moderating role of network capabilities. International Entrepreneurship and Management Journal, 12, 1103-1126.

Srećković, M. (2018). The performance effect of network and managerial capabilities of entrepreneurial firms. Small Business Economics, 50, 807-824.

Sully de Luque, M. S., Washburn, N. T., Waldman, D. A., \& House, R. J. (2008). Unrequited profit: How stakeholder and economic values relate to subordinates' perceptions of leadership and firm performance. Administrative Science Quarterly, 53, 626-654.

Tang, Z., \& Tang, J. (2012). Stakeholder-firm power difference, stakeholders' CSR orientation, and SMEs' environmental performance in China. Journal of Business Venturing, 27, 436-455.

Tushman, M. L., \& Romanelli, E. (1985). Organizational evolution: A metamorphosis model of convergence and reorientation. In L. L. Cummings \& B. M. Staw (Eds.), Research in Organizational Behavior, Vol. 7. Greenwich, CT: JAI Press, Inc.

Udayasankar, K. (2008). Corporate social responsibility and firm size. Journal of Business Ethics, 83, 167-175.

Wang, Q., Dou, J., \& Jia, S. (2016). A meta-analytic review of corporate social responsibility and corporate financial performance: The moderating effect of contextual factors. Business \& Society, 55, 1083-1121. 
Wiersema, M. F., \& Bantel, K. A. (1992). Top management team demography and corporate strategic change. Academy of Management Journal, 35, 91-121.

Wood, D. J. (1991). Corporate social performance revisited. Academy of Management Review, 16, 691-718.

\section{BIOGRAPHICAL SKETCH OF AUTHORS}

Sammy G. Muriithi, DBA, is an assistant professor of Management in the College of Business at the University of Central Oklahoma. His primary areas of research interest include corporate social responsibility and sustainability, corporate governance, mergers and acquisitions, and family business.

Bruce A. Walters is the Edward L. Moyers Endowed Professor in the Department of Management in the College of Business at Louisiana Tech University. His teaching, research, and consulting interests include corporate governance, acquisitions, strategic decision processes, top executive characteristics, and corporate social responsibility. His research has appeared in several journals, including Academy of Management Journal, Strategic Management Journal, Journal of Management, Strategic Organization, Journal of Business Ethics, and Journal of Business Research.

Otis W. Gilley is the Clarke Williams/CenturyLink Endowed Professor and Head, Department of Economics and Finance at Louisiana Tech University. His teaching and research include microeconomics and econometrics. His research has appeared in several journals, including American Economic Review, Management Science, Review of Economics and Statistics, Southern Economic Journal, Journal of Business and Economic Statistics, and Economic Inquiry. 